\title{
Spatial Autocorrelation Analysis among Subpopulations of Salix koriyanagi in Swampy Area at the Namgang River, Korea
}

\section{Man Kyu Huh*}

Department of Molecular Biology, Dongeui University 995 Eomgwangno, Busanjin-gu, Busan 614-714, Korea

Received June 25, 2008 / Accepted October 24, 2008

\begin{abstract}
Salix koriyanagi is a deciduous shrub and native to Korea. The spatial distribution of multilocus allelic frequencies and geographical distances of the natural population in upper swampy area at the Namgang River in Korea were studied. The species showed a significant positive and negative spatial autocorrelation according to geographical distances as measured by Moran's I. Genetic similarity of individuals was found among subpopulations at up to a scale of a $12 \mathrm{~m}$ distance, and this was partly due to a combination of allelic frequencies, and therefore, a significant spatial autocorrelation was composed of a scale of $12 \mathrm{~m}$ intervals. Within S. koriyanagi in swampy area at the Namgang River, a strong spatial structure was observed for allozyme markers, indicating a migration within subpopulations.
\end{abstract}

Key words : Moran's I, Salix koriyanagi, spatial autocorrelation

\section{Introduction}

Genetic variation in plant populations are also nonrandomly distributed [8]. Fine-scale genetic structure is evident within plant populations when the spatial distribution of genetic variation among individuals is random. A number of evolutionary and ecological process affect the development and maintenance of genetic structure within plant populations $[6,11,17]$.

In theory, genetic differentiation over short distances may occur either as a result of spatially variable selection or localized genetic drift, provided that gene flow is sufficiently restricted [6]. Indirect evidence for genetic correlations between neighboring plants has been obtained from data on mating systems [9]. Localized seed and pollen dispersals produce family clusters within these populations [7].

Salix koriyanagi Kimura ex Goerz is a deciduous shrub and native to Korea, but is widely grown by the Japanese for use in basketry [13]. S. koriyanagi is a large, upright, multibranched shrub, which can reach a height of 2-3 $\mathrm{m}$ at maturity. Young branches are slender, shiny, very flexible, pale green in color and yellowish under the bark. Bark on older stems is yellowish gray. Leaves are either opposite or alternate, 2 to 4 inches long, narrow, and slightly toothed along the edges. They will be shades of pale pink and

\section{*Corresponding author}

Tel : +82-51-890-1529, Fax : +82-51-890-1521

E-mail : mkhuh@deu.ac.kr brown when emerging. Flowers are produced from February to March. Male and female flowers are held in separate densely flowered, cylindrical catkins. The stamens of the male flowers are dark purple when the flowers first open, becoming red, orange, and then yellow. S. koriyanagi have been chosen to analyze a system to study habitat selection in spatiotemporally fluctuating environments. It will be assumed that the fitness of individuals in each habitat is a linear function of population density in that habitat and has a stochastic element that may or may not be correlated with the other habitat. At the start of each year, the adults will select habitat according to the expected fitness rewards in each habitat. The swamp area is located on upper part of the Namgang River. The area is less prone to effects of drought in winter and flooded during summer. It is expected to provide useful experimental conditions because of the undisturbed and isolated sites.

The purpose of this paper was to describe a statistical analysis for detecting a species association which is valid even when the assumption of within- species spatial randomness is violated. Two questions are addressed: 1) is there a spatial genetic structure within this population? and 2) if so, what is the spatial pattern of variation and is it the same for all loci?

\section{Materials and Methods}

\section{Sampling procedure}

The study was conducted from May to September 2007, 
on swampy area at the Namgang River, Mangi-ri, Gonmyeong-myeon, Sacheon-shi, Gyeoungsangnam-do, and involved mapping and sampling of a total of 160 individuals from eight subpopulations (Fig. 1). One leaf per plant was sampled. tissues gathered from natural populations were labeled and then refrigerated in plastic bags for 1 to 2 days, until enzyme extraction was carried out. The distance between selected individuals was about 1.0 $\mathrm{m}$, to avoid including those with a common lineage by vegetative reproduction.

Numerical simulations of previous analyses were performed to investigate the significant differences at various distance scales, i.e., 0.0-1.0, 0.0-2.0 m, and so on. However, no significant population structure was found within the $6.0 \mathrm{~m}$ distance classes by means of Moran's I, and a significant population structure was revealed beyond $6.0 \mathrm{~m}$. Thus, the distance classes are 0.0-6.0 m (class I), 6.0-12.0 m (class II), 12.0-18.0 m (class III), 18.0-24.0 m (class IV), 24.0-30.0 m (class V), 30.0-36.0 m (class VI), 36.0-42.0 m (class VII), and 42.0-48.0 $\mathrm{m}$ (class VIII). The codes of classes are the same as in the distance classes (Fig. 1) and are listed Tables $1 \sim 3$.

\section{Allozyme analysis}

Approximately 1.0 of $1.2 \mathrm{~g}$ biomass shoot tissues were ground with a cold mortar and pestle in 300 to $400 \mu \mathrm{l}$ of extraction buffer $(0.05 \mathrm{ml}$ of $0.1 \%$-mercaptoethanol, 0.001 M EDTA, $0.01 \mathrm{M}$ potassium chloride, $0.01 \mathrm{M}$ magnesium chloride hexahydrate, $4 \% \mathrm{w} / \mathrm{v} 1 \mathrm{~g}$ PVP, $0.10 \mathrm{M}$ Tris- $\mathrm{HCl}$ buffer, pH 8.0).

Electrophoresis was performed using $12.0 \%$ starch gels according to the methods by Soltis et al. [21]. Eight enzyme systems were assayed in this study. Glucose phosphate isomerase (GPI) and phosphoglucomutase (PGM) were resolved on system 9 of Soltis et al. [21]. Isocitrate

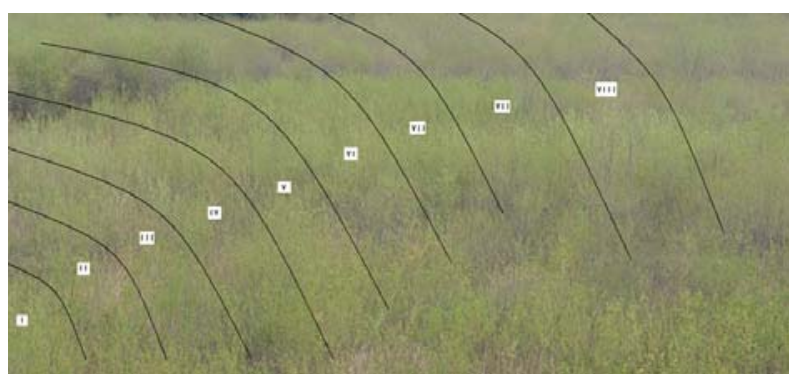

Fig. 1. Map illustrating geographical localities at swampy area in the Namgang River. The collection sites or classes are identified by code numbers. dehydrogenase (IDH), malate dehydrogenase (MDH), and 6-phosphogluconate dehydrogenase (PGD) were resolved on system 10 of Soltis et al. [21], Shikimate dehydrogenase (SKD), leucine aminopeptidase (LAP), and peroxidase (PER) were resolved on system Morpholine-citrate of Clayton and Tretiak [4].

\section{Statistical measures of genetic structure}

All monomorphic and polymorphic allozyme bands visible by eye were scored, and only unambiguously scored bands were used in the analyses.

The spatial structure of locus variations was quantified by Moran's I, a coefficient of spatial autocorrelation (SA) $[19,20]$. As applied in this study, Moran's I quantifies the genetic similarity of pairs of spatially adjacent individuals relative to the population sample as a whole. The value of I ranges between +1 (completely positive autocorrelation, i.e., paired individuals have identical values) and -1 (completely negative autocorrelation). Each plant was assigned a value depending on the presence or absence of a specific allele. If the $i$ th plant was a homozygote for the allele of interest, the assigned pi value was 1 , while if the allele was absent, the value 0 was assigned.

Pairs of sampled individuals [total number of pairs: $(120 \times 119) / 2=7,140$ ] were classified according to the Euclidean distance, dij, so that class $\mathrm{k}$ included dij satisfying $\mathrm{k}-1<\mathrm{dij}<\mathrm{k}+1$, where $\mathrm{k}$ ranges from 1 to 8 . The interval for each distance class was $6 \mathrm{~m}$ (see "Discussion"). Moran's I statistic for class $\mathrm{k}$ was calculated as follows:

$$
I(\mathrm{k})=\mathrm{n} \sum \mathrm{i} \sum \mathrm{j}(\mathrm{i} \neq \mathrm{j}) W \mathrm{ijZiZj} / S \sum \mathrm{Zi}^{2}
$$

where $\mathrm{Zi}$ is $p i-\mathrm{p}$ ( $\mathrm{p}$ is the average of $p i$ ); Wij is 1 if the distance between the $i$ th and $j$ th plants is classified into class $\mathrm{k}$; otherwise, Wij is $0 ; \mathrm{n}$ is the number of all samples and $S$ is the sum of $W i j\left\{\sum i \sum j(i \neq j) W i j\right\}$ in class $k$. Under the randomization hypothesis, $I(\mathrm{k})$ has the expected value $\mathrm{u} 1=-1 /(\mathrm{n}-1)$ for all $\mathrm{k}$. Its variance, $\mathrm{u} 2$, has been given, for example, in Sokal and Oden [19]. Thus, if an allele is randomly distributed for class $\mathrm{k}$, the normalized $I(\mathrm{k})$ for the standard normal deviation (SND) for the plant genotype, $\mathrm{g}(\mathrm{k})=\{I(\mathrm{k})-\mathrm{u} 1\} / \mathrm{u} 2^{1 / 2}$, asymptotically has a standard normal distribution [5]. Hence, SND $\mathrm{g}(\mathrm{k})$ values exceeding 1.96, 2.58 , and 3.27 are significant at the probability levels of $0.05,0.01$, and 0.001 , respectively.

All pairwise comparisons of geographic and genetic distances among the analyzed individuals were used for the 
definition of the so-called Fr function [22]. Like Moran's I, this function provides a method for investigating spatial autocorrelation, i.e., the correlation between geographic and genetic distances under isolation by the distance model. For every distance class, $r$, the relative frequency of individuals with an identical haplotype to $x$ is calculated as $\{\operatorname{Ir}(\mathrm{r})\}$. Then it can be calculated values of the Fr function as:

\section{$\operatorname{Fr}(\mathrm{r})=\left\{\operatorname{Ir}(\mathrm{r})-\sum \mathrm{pi}^{2}\right\} /\left(1-\sum \mathrm{pi}^{2}\right)$}

where pi is the relative frequency of haplotype $i$ for the entire populations [3].

\section{Results}

\section{Genetic diversity}

The level of genetic variation was high in eight subpopulations of $S$. koriyanagi (Table 1). Nine of 15 loci $(60.0 \%)$ showed polymorphism in at least one subpopulation, while the remaining six (Idh-2, Lap-1, Lap-2, Mdh-1, Per-3, and Gpi-2) were monomorphic in all populations. Therefore, the data on these loci were omitted from "Results" and "Discussion" in this paper. The majority of the polymorphic loci expressed two (Skd-2, Idh-1, Gpi-1, and Pgm) or three alleles (Skd-1, Mdh-2, Per-2 and Pgd-2). Per-1 was three. An average of $46.7 \%$ of the loci was polymorphic within subpopulations, with the values ranging from 40.0 to $53.3 \%$.

In a simple measure of intraclass variability by the percentage of polymorphic bands, class XI exhibited the lowest

Table 1. Measures of genetic variation for allozymes generated among eight classes of Salix koriyanagi used to detect polymorphism among genotypes

\begin{tabular}{cccccccc}
\hline $\begin{array}{c}\text { Code } \\
\text { of class }\end{array}$ & Pp & A & Ae & Ap & Hop (SD) & Hep (SD) \\
\hline I & 53.3 & 1.73 & 1.56 & 2.38 & $0.137(0.019)$ & $0.271(0.062)$ \\
II & 46.7 & 1.73 & 1.55 & 2.57 & $0.119(0.019)$ & $0.254(0.063)$ \\
III & 40.0 & 1.67 & 1.46 & 2.67 & $0.108(0.017)$ & $0.216(0.060)$ \\
IV & 46.7 & 1.80 & 1.54 & 2.71 & $0.116(0.017)$ & $0.247(0.063)$ \\
V & 53.3 & 1.87 & 1.54 & 2.63 & $0.145(0.019)$ & $0.272(0.064)$ \\
VI & 53.3 & 1.60 & 1.43 & 2.13 & $0.130(0.020)$ & $0.245(0.054)$ \\
VII & 46.7 & 1.60 & 1.39 & 2.20 & $0.098(0.018)$ & $0.180(0.054)$ \\
VIII & 46.7 & 1.60 & 1.39 & 2.29 & $0.113(0.020)$ & $0.215(0.056)$ \\
Mean & 46.7 & 1.68 & 1.48 & 2.45 & $0.121(0.007)$ & $0.238(0.021)$ \\
\hline
\end{tabular}

1)Percentage of polymorphism (Pp), mean number of alleles per locus (A), effective number of alleles per locus (Ae), expected heterozygosity (Hep), and observed heterozygosity (Hop). variation $(40.0 \%)$. Three classes (I, V, and VI) showed the highest value $(53.3 \%)$ of the eight classes (Table 1). Although the S. koriyanagi population was isolated, and patchily distributed, it maintained a high level of genetic diversity. For example, the average observed number of alleles (A) was 1.68 across classes, ranging from 1.60 for the class, with the lowest mean number of alleles to 1.87 for the class with the highest mean. The effective number of alleles (Ae) was similar for all classes $(1.39 \sim 1.56)$. The mean gene diversity within populations (Hep) was 0.238. Class V had the highest genetic diversity (0.272), while class VII had the lowest (0.180). The mean Hep of S. koriyanagi showed a significant difference among subpopulations (by paired t-test).

\section{Analysis of spatial autocorrelation}

The coefficient of spatial autocorrelation, Moran's $I$, for polymorphic loci is presented in Table 2. Moran's I of $S$. koriyanagi significantly differed from the expected value in only 34 of 72 cases $(47.2 \%)$. Thirteen of these values $(38.2 \%)$ were negative, indicating a partial genetic dissimilarity among pairs of individuals in the eight distance classes. Twenty-one of the significant values (61.8\%) were positive, indicating genetic similarity among individuals in the first two distance classes (I and II) except for one locus $(S k d-1)$, i.e., pairs of individuals can separate by more than $12 \mathrm{~m}$. Many Moran's I values of IV and V distance classes except for three locus (Skd-1, Gpi-1, and Pgm), were positive and Moran's I values of VI distance class except $S k d-1$ were negative. Thus, when Moran's I values started from IV distance class, pairs of individuals can also separate by more than $12 \mathrm{~m}$. Namely significant aggregations of an identical allele were partially observed at eight markers except for the Skd-1 marker within these IV and V classes.

Separate counts for each type of joined alleles and for each distance class of separation were tested for significant deviation from random expectations by calculating the SND. Figs. 2 and 3 show the distribution of SND for S. koriyanagi across the distance classes. $S k d-2, I d h-1$, and $M d h-2$ showed significantly positive SND values within distance class II (Fig. 2). All loci except $S k d-1$ had negative SND values beyond class III. As a matter of course. Skd-1 had first negative SND value at class V. In S. koriyanagi, the population structure of the distribution of allelic frequencies consists of a scale of $12.0 \mathrm{~m}$ intervals. However, no spatial structure of allelic frequencies was found for 
Table 2. Spatial autocorrelation coefficients (Moran's I) of nine loci among eight distance classes for S. koriyanagi

\begin{tabular}{|c|c|c|c|c|c|c|c|c|}
\hline \multirow{2}{*}{ Loci } & \multicolumn{8}{|c|}{ Distance classes } \\
\hline & I & II & III & IV & V & VI & VII & VIII \\
\hline Gpi-1 & $0.451^{\text {*** }}$ & $0.389^{* k}$ & -0.135 & -0.171 & 0.096 & -0.187 & 0.037 & -0.149 \\
\hline$I d h-1$ & $0.368^{* * *}$ & $0.237^{*}$ & $-0.182^{* *}$ & 0.013 & 0.022 & $-0.204^{*}$ & 0.042 & $0.272^{*}$ \\
\hline$M d h-2$ & $0.311^{* *}$ & $0.257^{*}$ & $-0.241^{*}$ & 0.042 & 0.068 & $-0.289^{*}$ & 0.141 & 0.113 \\
\hline Per-1 & $0.390^{* * *}$ & $0.277^{*}$ & $-0.204^{*}$ & 0.124 & 0.149 & $-0.334^{* *}$ & 0.222 & 0.163 \\
\hline Per-2 & $0.511^{\text {*** }}$ & $0.453^{\text {tokt }}$ & -0.002 & 0.119 & 0.179 & $-0.252^{*}$ & 0.137 & 0.112 \\
\hline$P g d$ & $0.448^{* * * *}$ & $0.434^{* \hbar k}$ & -0.061 & 0.075 & $0.224^{*}$ & $-0.228^{*}$ & 0.033 & $0.365^{* *}$ \\
\hline Pgm & $0.365^{\text {*k }}$ & 0.163 & $-0.203^{*}$ & -0.093 & 0.143 & $-0.222^{*}$ & 0.134 & 0.050 \\
\hline skd-1 & $0.424^{* * *}$ & $0.344^{* *}$ & $0.266^{*}$ & 0.121 & $-0.198^{*}$ & 0.107 & 0.177 & $0.201^{*}$ \\
\hline$s k d-2$ & $0.439^{* * * *}$ & 0.102 & $-0.250^{*}$ & 0.116 & 0.175 & $-0.232^{*}$ & 0.121 & 0.062 \\
\hline
\end{tabular}

* $p<0.05$ ** $p<0.01 * * * p<0.001$.

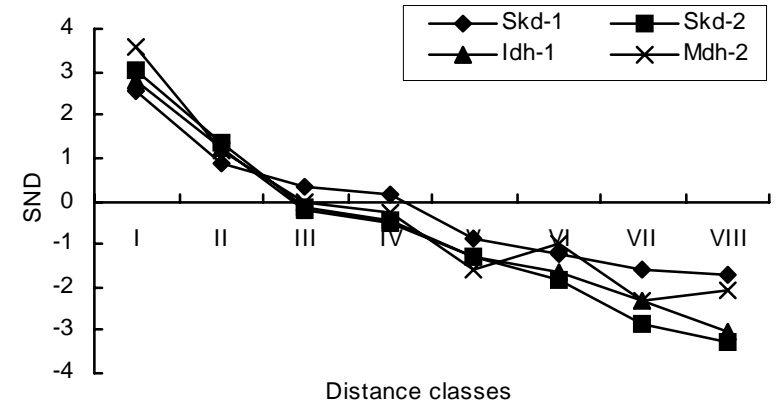

Fig. 2. Correlograms for the swampy area at the Namgang River of Salix koriyanagi using values of Moran's I for four loci (Skd-1, Skd-2, Idh-1, and Mdh-2).

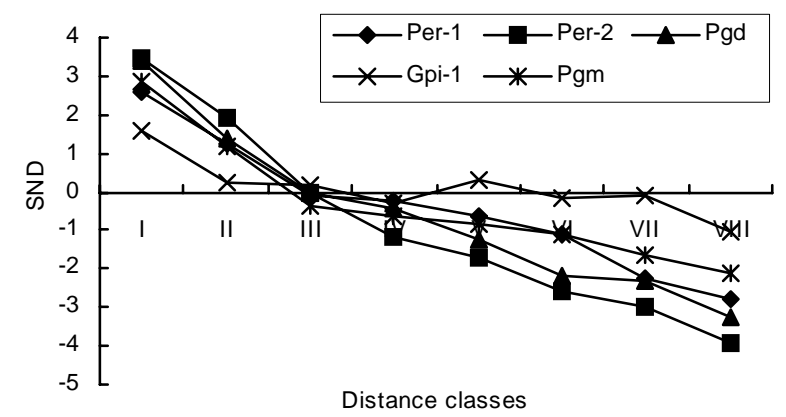

Fig. 3. Correlograms for the swampy area at the Namgang River of S. koriyanagi using values of Moran's I for five loci (Gpi-1, Per-1, Per-2, Pgd, and Pgm).

one marker (Gpi-1) within the natural population of $S$. koriyanagi. Gpi-1, Per-1, Per-2, Pgd, and Pgm showed significantly positive SND values within distance class II (Fig. 3). Thus, genetic dissimilarity among pairs of individuals could found by more than $12 \mathrm{~m}$. This suggests that neighboring patches in which there are different alleles are predominantly 12 to $18 \mathrm{~m}$ apart, on average. The comparison of $F r$ values to a logistic regression indicated that a highly

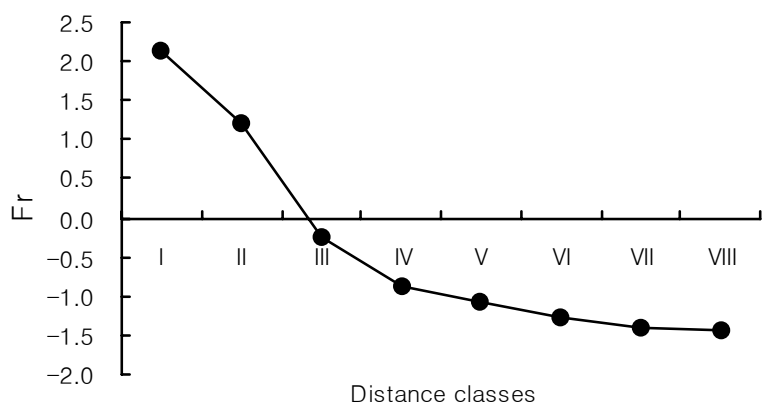

Fig. 4. Genetic versus geographic distances of the swampy area at the Namgang River in Korea. Values of the Fr function are given.

Table 3. Number of loci exhibiting significant differences in allelic frequencies (upper diagonal) and genetic distances (low diagonal) between classes

\begin{tabular}{ccccccccc}
\hline Class & I & II & III & IV & V & VI & VII & VIII \\
\hline I & - & 0 & 2 & 4 & 4 & 5 & 5 & 7 \\
II & 0.003 & - & 1 & 3 & 4 & 2 & 5 & 6 \\
III & 0.036 & 0.033 & - & 0 & 2 & 5 & 4 & 6 \\
IV & 0.039 & 0.007 & 0.009 & - & 3 & 2 & 5 & 5 \\
V & 0.038 & 0.016 & 0.016 & 0.017 & - & 1 & 3 & 4 \\
VI & 0.047 & 0.027 & 0.029 & 0.033 & 0.010 & - & 2 & 3 \\
VII & 0.054 & 0.026 & 0.023 & 0.025 & 0.021 & 0.018 & - & 0 \\
VIII & 0.042 & 0.024 & 0.023 & 0.028 & 0.017 & 0.010 & 0.007 & - \\
\hline
\end{tabular}

significant percentage of genetic variation in the subpopulation could be explained by isolation by distance (Fig. 4). It is almost consisted the result of Moran's $I$.

Pairwise comparison of regions was included in Table 3. The numbers of loci exhibiting significant differences in allelic frequencies between regions would be a good indicator of differentiation if the sample sizes are equal. There were not significant differences between classes I and II, classes III and IV, and classes VII and VIII. 


\section{Discussion}

S. koriyanagi (0.238) maintains a higher than average level of genetic diversity compared with other plant species: temperate-zone species (0.146), dicots (0.136), species with a sexual reproduction mode (0.151), and those with a long-lived woody habit (0.177) [10]. Especially, For example, its genetic diversity at 0.238 is higher than that of early successional species (0.149), middle successional species (0.141). The early successional stage is colonized by mosses, fireweed, and cottonwood and the willows (S. koriyanagi) begin as prostrate plants but later grow into erect shrubs [12].

A significant positive value of Moran's I indicated that pairs of individuals separated by distances that fell within distance class $\mathrm{k}$ had similar genotypes (gene frequencies), whereas a significant negative value indicated that they had dissimilar genotypes. The overall significance of individual correlograms was tested using Bonferroni's criteria [18]. The results revealed that genetic similarity was shared among individuals within up to a scale of a $12 \mathrm{~m}$ distance. Thus there were directly structured for the presence of genetic correlations between neighbors at this scale.

Although no distinct spatial structure of allelic frequencies was found for either of the 3 loci (Skd-1, Gpi-1, and Pgm) within the natural subpopulations of S. koriyanagi, many significant aggregations of an identical allele were partially observed at the six loci for some classes. The results from this study are consistent with the supposition that a plant population is subdivided into local demes, or neighborhoods of related individuals [14]. Previous reports on the local distribution of genetic variability suggested that microenvironmental selection and limited gene flow are the main factors causing substructuring of alleles within a population $[7,9]$. Local genetic differentiation at isozyme or other marker loci caused by microenvironmental heterogeneity has been observed in a variety of plant species. Those loci showed significant aggregation of an identical allele, which persists for generations, as long as the same microenvironmental conditions continue. This persistence was demonstrated, for example, in the Got-1 locus in lodgepole pine [9] and for the genetic variation in quantitative traits of Impatiens capensis [1]. In the present study, most loci $(47.2 \%)$ showed significant aggregation in the Korean S. koriyanagi population. This aggregation, however, did not persist at all loci, thereby excluding micro- environmental selection as being the main cause for allelic aggregation.

It is important to infer the genetic patch width because it defines the spatial scale within which individuals have similar genetic backgrounds. The distance at which mean Moran's I values first intercept the u1 value provides a measure of the shortest diameter of irregularly shaped patches [5].

Possible contributing factors include differences in density and topography but not human interference. Most populations in our study experience annual, severe demographic bottlenecks due to drought and floods. In addition, reduce of populations are expected to diverge genetically due to drift, the random loss of alleles having individuals due to sporadically fishing. The topology of subpopulations from class I to III is steep slopes, whereas, the subpopulations in classes IV $\sim$ VIII are flat or gently sloping.

In simulations, Ohsawa et al. [15] and Epperson [7] showed that local genetic differentiation is very sensitive to the degree of actual gene dispersal. An indirect estimate of gene flow, based on the mean Gst (the proportion of total genetic diversity partitioned among populations), was moderate $(\mathrm{Nm}=2.85)$ in Korean classes. Levels of gene flow calculated in the present study are of sufficient magnitude to counterbalance genetic drift, thus playing a major role in shaping the genetic structure of $S$. koriyanagi.

If drift were the only force structuring genetic variation, it would not expect all of the markers to produce similar correlograms, or to decline with increasing distance classes, with the patch size for positive autocorrelation determined by the neighborhood area, although the actual spatial patterns would be uncorrelated among markers [20]. If the observed differences in spatial structure among markers are significant, these cannot be explained by drift alone. Unfortunately, no precise statistical procedures exist for testing the significance of differences among Moran's I-correlograms [1]. Moreover, since different markers displayed different amounts of genetic determination, the power or precision of the I-statistic may differ among markers. Nevertheless, most correlograms showed significance at a scale of $12 \sim 18 \mathrm{~m}$.

\section{References}

1. Argyres, A. Z. and J. Schmitt. 1991. Microgeographic genetic structure of morphological and life history traits in 
a natural population of Impatiens capensis. Evolution 45, 178-189.

2. Barrett, S. C. H., C. G. Eckert and B. C. Husband. 1993. Evolutionary processes in aquatic plant populations. Aquat. Bot. 44, 105-145.

3. Cassens, I., R. Tiedemann, F. Suchentrunk and G. B. Hartl. 2000. Mitochondrial DNA variation in the European otter (Lutra lutra) and the use of spatial autocorrelation analysis in conservation. J. Hered. 91, 31-34.

4. Clayton, J. W. and D. N. Tretiak. 1972. Amine-citrate buffers for $\mathrm{pH}$ control in starch gel electrophoresis. J. Fish. Res. Board Can. 29, 1169-1172.

5. Cliff, A. D. and J. K. Ord. 1971. Evaluating the percentage points of a spatial autocorrelation coefficient. Geographical Analysis 3, 51-62.

6. Dewey, S. E. and J. S. Heywood. 1988. Spatial genetic structure in a population of Psychotria nervosa. I. Distribution of genotypes. Evolution 42, 834-838.

7. Epperson, B. K. 1990. Spatial autocorrelation of genotypes under directional selection. Genetics 124, 757-771.

8. Epperson, B. K. 1995. Fine-scale spatial structure: correlations for individual genotypes differ from those for local gene frequencies. Evolution 49, 1022-1026.

9. Epperson, B. K. and R. W. Allard. 1989. Spatial autocorrelation analysis of the distribution of genotypes within populations of lodgepole pine. Genetics 121, 369-377.

10. Hamrick, J. L., M. J. W. Godt and S. L. Sherman-Broyles. 1992. Factors influencing levels of genetic diversity in woody plant species. New Forests 6, 95-124.

11. Kalisz, S., J. D. Nason, F. A. Hanzawa and S. J. Tonsor. 2001. Spatial population genetic structure in Trillium grandiflorum: the roles of dispersal, mating, history, and selection. Evolution 55, 1560-1568.

12. Krebs, C. J. 2001. Ecology. The Experimental and Analysis of Distribution and Abundance. pp. 695, Addison Wesley
Longman, Inc., San Francisco, California.

13. Lee, C. S., Y. H. You and G. R. Robinson. 2002. Secondary succession and natural habitat restoration in abandoned rice fields of central Korea. Restoration Ecology 10, 306-314.

14. Levin, D. A. 1984. Inbreeding depression and proximitydependent crossing succession in Phlox drummondii. Evolution 38, 116-127.

15. Levy, F. and C. L. Neal. 1999. Spatial and temporal genetic structure in chloroplast and allozyme markers in Phacelia dubia implicate genetic drift. Heredity 82, 422-431.

16. Ohsawa, R., N. Furuya and Y. Ukai. 1993. Effects of spatially restricted pollen flow on spatial genetic structure of an animal-pollinated allogamous plant. Heredity 71, 64-73.

17. Parker, K. C., J. L. Hamrick, A. J. Parker and J. D. Nason. 2001. Fine scale genetic structure in Pinus clausa (Pinaceae) populations: effects of distribution history. Heredity 87, 99-113.

18. Sakai, R. R. and N. L. Oden. 1983. Spatial pattern of sex expression in silver maple (Acer saccharium L.): Morisita's index and spatial autocorrelation. Am. Nat. 122, 489-508.

19. Sokal, R. R and N. L. Oden. 1978a. Spatial autocorrelation in biology 1. Methodology. Biol. J. Linn. Soc. 10, 199-228.

20. Sokal, R. R and N. L. Oden. 1978b. Spatial autocorrelation in biology 2. Some biological implications and four applications of evolutionary and ecological interest. Biol. J. Linn. Soc. 10, 229-249.

21. Soltis, D. E., C. H. Haufler, D. C. Darrow and G. J. Gastony. 1983. Starch gel electrophoresis of ferns: A compilation of grinding buffers, gel and electrode buffers, and staining schedules. Am. Fern. J. 73, 9-27.

22. Van Dijk, H. 1987. A method for the estimation of gene flow parameters from a population structure caused by restricted gene flow and genetic drift. Theor. Appl. Genet. 73, 724-736.

\section{초록 : 남강 습지에 분포하는 키버들 집단의 공간적 상관 분석}

\section{허 만 규}

(동의대학교 분자생물학과)

키버들(Salix koriyanagi)은 관목으로 한국에 고유종이다. 전분 젤 전기영동을 사용하여 남강 상류 저습지에 분 포하는 키버들 집단에서 유전적 다양성과 집단구조를 분석하기 위해 집단을 세분하였다. Moran's I값으로 세분화 된 $1.0 \mathrm{~m}$ 간격별 구간 내 개체들의 대립유전자좌위에서 유의한 상관을 조사한 결과 약 $6 \mathrm{~m}$ 간격 내 개체들의 뭉침이 나타났으며, $12 \mathrm{~m}$ 이상일 경우 유의한 차이가 나타났다. 따라서 키버들의 경우 집단구조가 $12 \mathrm{~m}$ 이내에 서 형성됨을 알 수 있었다. 대부분의 집단이 제한된 유전자 유동과 유효집단의 감소가 예상되며, 겨울철 가뭄과 여름철 홍수로 심한 병목을 유발하고, 주기적인 홍수와 배수로 인한 개체 수의 교란이 발생한 것으로 판단된다. 